\title{
Study of Proteolytic and Lipolytic Activities of Pseudomonas spp. Isolated From Pasteurized Milk in Tunisia
}

\author{
Olfa Samet-Bali ${ }^{1}$, Imène Felfoul ${ }^{1}$, Rouaa Lajnaf ${ }^{1}$, Hamadi Attia ${ }^{1} \&$ Mohamed Ali Ayadi ${ }^{1}$ \\ ${ }^{1}$ Département de Biologie, Laboratoire Valorisation, Analyse et Sécurité des Aliments (LAVASA), Ecole \\ Nationale d'Ingénieurs de Sfax, Route de Soukra, B.P.W, Sfax, Tunisia \\ Correspondence: Olfa Samet-Bali, Département de Biologie, Laboratoire Valorisation, Analyse et Sécurité des \\ Aliments (LAVASA), Ecole Nationale d'Ingénieurs de Sfax, Route de Soukra, B.P.W, Sfax 3038, Tunisia. Tel: \\ 216-97-556-136. E-mail: olfabali@yahoo.fr
}

\author{
Received: April 11, 2013 Accepted: May 20, 2013 Online Published: June 15, 2013 \\ doi:10.5539/jas.v5n7p46 URL: http://dx.doi.org/10.5539/jas.v5n7p46
}

\begin{abstract}
Psychrotrophic bacteria have been recognized as a recurring problem in refrigerated storage and distribution of perishable food products. This study was performed to isolate, characterize and evaluate the prevalence of Pseudomonas spp. in pasteurized milk. Thirty (30) pasteurized milk samples were collected aseptically from different dairy shops, supermarkets and groceries in different areas in Sfax Governorate, Tunisia and analyzed for total viable count and Pseudomonas spp. occurrence and explain their proteolytic and lipolytic activities. The results showed that Pseudomonas aeruginosa was found to be the predominant from the Pseudomonas spp. followed by Pseudomonas fluorescens. The total viable count was $(3.25 \pm 0.02) \times 10^{4} \mathrm{CFU} / \mathrm{ml}$. Out of 8 Pseudomonas spp. isolates that were examined for proteolytic and lipolytic activities; two isolates had proteolytic activity, while two had lipolytic activity and four isolates had both.
\end{abstract}

Keywords: Pseudomonas aeruginosa, Pseudomonas fluorescens, proteolytic, lipolytic activities

\section{Introduction}

Milk has many nutritious qualities that make it an important part of children's diet. To produce the best quality milk and to achieve all the nutritious benefits of it, the highest quality raw milk must be obtained. Pasteurization and shelf stable milk products through ultra high temperature (UHT) continuous flow sterilization are available (Goff \& Griffiths, 2006). The conditions of heat treatment used for pasteurization depend on the final product; lower temperatures are used for refrigerated products and higher heat treatments are used for products stored at room temperature (United States Code of Federal Regulation [USCFR], 2006). Psychrotrophic bacteria have been recognized as a recurring problem in the refrigerated storage and distribution of fluid milk, and perishable dairy products for several decades (Singh, Wani, Karim, \& Langowski, 2012). So, the psychrotrophic have received increased attention by investigators during recent years, because modern developments in the handling and transportation of milk have resulted in milk being held for longer period at refrigeration temperature before processing, manufacturing or consumption. Some psychrotrophic bacteria may grow at a temperature of $7^{\circ} \mathrm{C}$ although their optimum temperature is higher. Rapid cooling and cold storage of raw milk favor the growth of psychrotrophic bacteria in milk (Barbano, Ma, \& Santos, 2006). They become dominant microflora during cold storage of milk and their extracellular enzymes, particularly proteases and lipases, contribute to the spoilage of milk products (Hantis-Zacharov \& Halpern, 2007).

Microbial growth and metabolism shorten the shelf life of milk by producing undesirable changes in aroma and taste attributes that influence consumer acceptability of the products (Fromm \& Boor, 2004). Factors limiting milk stability are well established: bacterial contamination (Kabir \& Niar, 2013), inadequate packaging system (Singh et al., 2012) and improper temperature control (Ben Moussa, Mankai, Ben Fekih, \& Hassouna, 2013). Vulnerability of milk's fat and protein to physical-chemical alterations can also lead to deterioration, thus, reducing its quality. Cromie (1991) reported that the factors which influence the shelf life of pasteurized milk include the quality of the raw material, the binomial temperature/time pasteurization, resistant microorganisms to pasteurization (particularly Psychrotrophic), the presence and activity of post pasteurization contaminants, the packaging system and storage temperature post pasteurization which had the greatest impact on the stability of the product as shelf life of pasteurized milk. Extra cellular lipolytic enzymes produced from psychrotrophics can 
produce deteriorate effects as rancid flavours and odours in milk and dairy products that make a subsequent reduction of shelf-life and the products become unacceptable to consumers (Downey, 1980).

The proteolytic enzymes produced by psycrotrophics in milk are more powerful in its action on milk proteins than that naturally present in milk and that produced by leucocytes even if present by great amount (Grieve \& Kitchen, 1985). Pseudomonas spp. produces a large number of extracellular toxins, which include phytotoxic factor, pigments, hydrocyanic acid, proteolytic enzymes (Baglinière et al., 2013), phospholipase and enterotoxins. Exotoxins are responsible for Pseudomonas spp. pathogenicity because it can produce leucopoenia, circulatory collapse, necrosis of liver, pulmonary edema, hemorrhage and kidney tubular necrosis. The enterotoxin produced is responsible for diarrhea disease.

High temperature for short times was less effective in destruction of the Pseudomonas spp. than that of temperature for long times because the condition created in the milk at high temperatures may response of injured cells (Cousin, 1982). Generally, they are considered incapable of surviving pasteurization and they may be post-processing contamination. Although, they can cause gastroenteritis if ingested in large number $\left(>10^{6}\right.$ cell $)$, but also the food would be clearly spoiled before such numbers would reached (Johnson, 1990). Moreover, its presence in milk and its products was considered as a possible indicator of fecal contamination. Also Pseudomonas aeruginosa has been implicated in epidemics of moderate to severe diarrhea in children in the form of enteric fever (Todar, 2004).

This study aimed to isolate, characterize and evaluate the prevalence of Pseudomonas spp. in pasteurized milk sold in Sfax Governorate, Tunisia. Also, observation of the proteolytic and lipolytic behavior of it in the pasteurized milk was investigated.

\section{Materials and Methods}

Thirty (30) samples of pasteurized milk were collected randomly from various local milk supermarkets in different areas in Sfax Governorate, Tunisia. Collected samples were examined for total viable cells and occurrence and behavior of Pseudomonas organisms. Psychrotrophic isolates were obtained from pasteurized milk by pouring plating appropriately diluted sample using nutrient agar. Incubation was done at $7^{\circ} \mathrm{C}$ for 10 days (Cousin, 2001). The psychrotrophic isolates were subjected to biochemical characterization after activating the culture in nutrient broth at $37^{\circ} \mathrm{C}$ for $24 \mathrm{~h}$ (Barrow \& Feltham, 1993).

\subsection{Identification of Pseudomonas Isolates}

The representative suspected colonies were purified and then identified according to Bergey's Manual of Systemic Bacteriology (1984) and API 20 NE kit (England). Pseudomonas isolates were subcultured onto nutrient agar (NA) plates and incubated at $30^{\circ} \mathrm{C}$ for $24 \mathrm{~h}$. Pure cultures were inoculated into nutrient broth and incubated overnight at $30^{\circ} \mathrm{C}$ prior to testing.

\subsection{Oxidation Fermentation Test}

Lactose negative, blue-black and greenish bright dark colonies were lactose positive as a result of incubation during $48 \mathrm{~h}$ at $30^{\circ} \mathrm{C}$. Among these, continuous studies were carried out on the lactose negative ones and these colonies were applied on the oxidation fermentation test. For Pseudomonas oxidative reaction, among the same samples of catalase $(+)$, motility $(+)$ and oxidase $(+)$ activities, colonies were studied on growth at 4 and $41^{\circ} \mathrm{C}$ which were first taken into consideration. So, Pseudomonas, which incubated into yeast extract medium were left at $4{ }^{\circ} \mathrm{C}$ for 7 to 10 days and at $41^{\circ} \mathrm{C}$ for $24 \mathrm{~h}$, respectively (Mickova, Lukasova, \& Konencny, 1989).

\subsection{Determination of the Proteolytic and Lipolytic Activities of Pseudomonas spp.}

Eight (8) strains belonging to Pseudomonas spp. Isolated previously from pasteurized milk samples were investigated for their proteolytic and lipolytic activities as described by Harrigan and McCance (Harrigan \& MacCance, 1976).

\subsubsection{Proteolytic Activity Using Skim Milk Agar}

Overnight cultures were spot inoculated onto milk agar, standard plate count agar supplemented with $10 \%$ sterile skim milk. The inoculated plates were incubated at 20 and $4^{\circ} \mathrm{C}$ for 10 days. The presence of transparent zones around the spots was recorded as positive strains referring to protease production, and subsequently flooded with $10 \% \mathrm{v} / \mathrm{v}$ acetic acid solution. Clear zone around the colonies after $1 \mathrm{~min}$ exposure were regarded as positive (Harrigan \& MacCance, 1976). 


\subsubsection{Lipolytic Activity}

Lipolytic counts (LP) were determined using NA containing tributyrin. The medium was prepared using $10 \mathrm{~g}$ of tributyrin and $28 \mathrm{~g}$ of NA. Plates were incubated at 20 and $4{ }^{\circ} \mathrm{C}$ for $72 \mathrm{~h}$ to determine viable LP. Lipolytic activity was determined by measuring clear zone around each colony (Harrigan \& MacCance, 1976).

\section{Results and Discusion}

\subsection{Incidence of Pseudomonas spp. among the Examined Samples}

The samples showed an average of total viable count of $(3.25 \pm 0.02) \times 10^{4} \mathrm{CFU} / \mathrm{ml}$. According to Prevention of Food Adulteration Act (PFA, 2007), total plate count of pasteurized milk should not exceed $30.000 \mathrm{CFU} / \mathrm{ml}$. However, it was observed that all the standard plate count were characterized by the predominance of typical small circular entire smooth and shining uncolored colonies. Furthermore, only this type of colony was evident in the plates used for taking psychrotrophic count (Table 1). The Pseudomonas spp. count was $(1.2 \pm 0.01) \times 10^{2} \mathrm{CFU} / \mathrm{ml}$ among different samples and the isolates were subjected to bacteriological examination as shown in Table 2 .

Table 1. Prevalence and count $(\mathrm{CFU} / \mathrm{ml})$ of Pseudomonas spp. in examined pasteurized milk samples

\begin{tabular}{llllll}
\hline \multirow{2}{*}{ No. of sample } & \multicolumn{2}{l}{ Positive samples } & Minimum & Maximum & Mean \pm SD \\
\cline { 2 - 3 } & No. & $\%$ & & & \\
\hline 30 & 8 & 26.66 & $1.2 \times 10$ & $2.1 \times 10^{2}$ & $(1.2 \pm 0.01) \times 10^{2}$ \\
\hline
\end{tabular}

Table 2. The bacteriological examination of Pseudomonas spp. in examined pasteurized milk samples

\begin{tabular}{|c|c|c|c|c|c|c|c|c|}
\hline No. of isolate & 1 & 2 & 3 & 4 & 5 & 6 & 7 & 8 \\
\hline Catalase & + & + & + & + & + & + & + & + \\
\hline Oxidase & + & + & + & + & + & + & + & + \\
\hline $\mathbf{O} / \mathbf{F}$ & $\mathrm{O}^{+} / \mathrm{F}^{-}$ & $\mathrm{O}^{+} / \mathrm{F}^{-}$ & $\mathrm{O}^{+} / \mathrm{F}^{-}$ & $\mathrm{O}^{+} / \mathrm{F}^{-}$ & $\mathrm{O}^{+} / \mathrm{F}^{-}$ & $\mathrm{O}^{+} / \mathrm{F}^{-}$ & $\mathrm{O}^{+} / \mathrm{F}^{-}$ & $\mathrm{O}^{+} / \mathrm{F}^{-}$ \\
\hline Lactose Fermentation & - & - & - & - & - & - & - & - \\
\hline Motility & + & + & + & + & + & + & + & + \\
\hline MR & - & - & - & - & - & - & - & - \\
\hline $\mathbf{V P}$ & - & - & - & - & - & - & - & - \\
\hline Citrate utilization & + & + & + & + & + & + & + & + \\
\hline Gelatin hydrolysis & + & + & + & + & + & + & + & + \\
\hline Indol production & - & - & - & - & - & - & - & - \\
\hline Nitrate reduction & + & + & + & + & + & + & + & + \\
\hline
\end{tabular}

The results showed that 8 samples were positive for occurrence of Pseudomonas spp., with a percentage of $26.66 \%$. Identity of the isolates was confirmed by using API 20 NE for detection and isolation of Pseudomonas spp.; 6 isolates of P. aeruginosa and 2 isolates of Pseudomonas fluorescens were detected. Many investigators indicated that some Pseudomonas spp. could survive heat treatment used in pasteurization of milk (Abad, Villafafila, Frias, \& Rodriguez-Fernandez, 1993). Incidence of $P$. aeruginosa in pasteurized milk has been reported by Kumaresan and Annalvilli (2008). According to them, post processing contamination led to the predominance of heat sensitive Pseudomonas spp. in pasteurized milk.

Quality defects in pasteurized milk are most often the result of microbial contamination, growth and spoilage. Microbial defects usually become evident in the finished product through shelf-life evaluations or consumer complaints. Post-pasteurization contamination with psychrotrophic spoilage bacteria is most detrimental. In most cases, product contamination is the result of insufficient cleaning and sanitation of the processing equipment and plant environment. Practices that are being followed in the dairy processing unit would have singled out psychrotrophics as the major category of spoilage organism (Alatossava \& Alatossava, 2007). 


\subsection{The Proteolytic and Lipolytic Activities of Pseudomonas spp.}

The high spoilage potential of Pseudomonas spp. is not only because of its ability to multiply at refrigeration temperatures but also because of their ability to produce thermostable proteases and lipases (Sorhaug \& Stepaniak 1997). The importance of proteases and lipases, which causes bacterial virulence, was proven in several studies. However, there was less study in the protease and lipase activities of Pseudomonas spp. This study showed that the Pseudomonas spp. isolates did not show proteolytic and lipolytic activities at $4{ }^{\circ} \mathrm{C}$, while at $20^{\circ} \mathrm{C}$ the $P$. aeruginosa and $P$. fluorescens isolates showed these activities as shown in Table 3: 2 isolates were positive for proteolytic; 2 isolates for lipolytic and 4 isolates for both proteolytic and lipolytic. This finding agrees with the findings of Dogan and Boor (2003). Psychrotrophics were implicated in many defects in milk and dairy products which are a problem resulting from prolonged refrigeration storage (Garg, 1990) and distribution of perishable food products. Pseudomonas spp. have been implicated in the spoilage of processed milk kept under chilled condition because of their capacity to multiply under refrigeration with the production of thermostable proteases and lipases (Rajmohan, 2002) which plays an important role in milk spoilage.

Table 3. Proteolytic and lipolytic activities of Pseudomonas spp. isolated from pasteurized milk samples.

\begin{tabular}{lllll}
\hline $\begin{array}{l}\text { Pseudomonas } \\
\text { isolate }\end{array}$ & $\begin{array}{l}\text { No. of tested } \\
\text { isolates }\end{array}$ & $\begin{array}{l}\text { Positive protyolytic } \\
\text { isolates }\end{array}$ & $\begin{array}{l}\text { Positive lipolytic } \\
\text { isolates }\end{array}$ & $\begin{array}{l}\text { Positive protyolytic and } \\
\text { lipolytic isolates }\end{array}$ \\
\hline P. aeruginosa & 6 & 1 & 1 & 3 \\
P. fluorescens & 2 & 1 & 1 & 1 \\
Total & 8 & 2 & 2 & 4 \\
\hline
\end{tabular}

\section{Conclusion}

Raw milk deteriorates in only a few days even when stored under refrigeration temperatures. In this study, the results cleared that after pasteurization, 8 samples from 30 samples were positive for occurrence of Pseudomonas spp., with a percentage of $26.66 \%$ that may be due to insufficient pasteurization or the post contamination by this genus and the temperature which milk and dairy products are exposed influences the type of microorganisms that will grow in them. As dairy equipment and utensils constitute the major source of many types of psychrotrophics in milk, so special attention should be considered in their cleaning and sanitation to produce milk of low bacterial count or even completely free of psychrotropics bacteria. The previous information indicated that psychrotrophics are still inevitable because they are widely distributed in nature, withstand sanitizers and can liberate heat stable enzyme causing spoilage of food and some of them considered as food borne pathogens. This knowledge increase attention toward the way by which the restriction of these microorganisms must be done.

\section{References}

Abad, P., Villafafila, A., Frias, J. D., \& Rodriguez-Fernandez, C. (1993). Extracellular lipolytic activity from Pseudomonas fluorescence biovar1 (Pseudomonas fluorescencs Ncl). Milchwissenschaft, 48(12), 680-683.

Alatossava, P. M., \& Alatossava, T. (2007). Antibiotic resistance of raw-milk associated psychrotrophic bacteria. Microbiological Research, 162, 115-123. http://dx.doi.org/10.1016/j.micres.2006.01.015

Baglinière, F., Matéos, A., Tanguy, G., Jardin, J., Briard-Bion, V., Rousseau, F., ... Gaucheron, F. (2013). Proteolysis of ultra high temperature-treated casein micelles by AprX enzyme from Pseudomonas fluorescens $\mathrm{F}$ induces their destabilisation. International Dairy Journal, 31, 55-61. http://dx.doi.org/10.1016/j.idairyj.2013.02.011

Barbano, D. M., Ma, Y., \& Santos, M. V. (2006). Influence of Raw Milk Quality on Fluid Milk Shelf Life. Journal of Dairy Science, 89, 15-19. http://dx.doi.org/10.3168/jds.S0022-0302(06)72360-8

Barrow, C. J., \& Feltham, R. K. A. (1993). Cowan and Steel's Manual for Identification of Medical Bacteria (3 ${ }^{\text {rd }}$ ed.). London: Cambridge University Press. http://dx.doi.org/10.1017/CBO9780511527104

Ben Moussa, O., Mankai, M., Ben Fekih, A., \& Hassouna, M. (2013). Effect of the lactoperoxidase system on proteolysis and physicochemical changes in ultra high temperature milk during storage. African Journal of Biotechnology, 12, 2041-2050.

Cousin, M. A. (1982). Presence and activity of psychrotrophic microorganisms in milk and dairy products. Journal of Food Protection, 45, 172-207. http://dx.doi.org/10.2105/9780875531755ch13 
Cousin, M. A., Jay, J. M., \& Vasavada, P. C. (2001). Psychrotrophic microorganisms. In F. P. Downes, \& K. Ito (Eds.), Compendium of methods for microbial examination of foods (pp. 159-164). Washington DC: APHA.

Cromie, S. J. (1991). Microbiological aspects of extended shelf life products. Australian Journal of Dairy Technology, 46, 101-104.

Dogan, B., \& Boor, K. J. (2003). Genetic diversity and spoilage potentials among Pseudomona ssp. isolated from fluid milk products and dairy processing plants. Applied and Environmental Microbiology, 69, 130-138. http://dx.doi.org/10.1128/AEM.69.1.130-138.2003

Downey, W. K. (1980). Flavor impairment from pre- and post manufacture lipolysis in milk and dairy products. Journal of Dairy Research, 47, 237- 252. http://dx.doi.org/10.1017/S0022029900021117

Fromm, H. I., \& Boor, K. J. (2004). Characterization of pasteurized fluid milk shelf-life attributes. Journal of Food Science, 69, 207-214. http://dx.doi.org/10.1111/j.1365-2621.2004.tb09889.x

Garg, S. K. (1990). Psychrotrophs in milk. Indian Journal of Dairy Science, 43(3), 433-440.

Goff, H. D., \& Griffiths, M. W. (2006). Major advances in fresh milk and milk products. Journal of Dairy Science, 89, 1163-1173. http://dx.doi.org/10.3168/jds.S0022-0302(06)72185-3

Grieve, P. A., \& Kitchen, B. J. (1985). Proteolysis in milk: the significance of proteinases originating from milk leucocytes and a comparison of the action of leucocyte bacterial and natural milk proteinases on casein. Journal of Dairy Research, 52, 101-112. http://dx.doi.org/10.1017/S0022029900023931

Hantis-Zacharov, E., \& Halpern, M. (2007). Cultural psychrotrophic bacterial communities in raw milk and their proteolytic and lipolytic traits. Applied and Environmental Microbiology, 73, 7162-7168. http://dx.doi.org/10.1128/AEM.00866-07

Harriga, W. F., \& MacCance, M. E. (1976). Laboratory Methods in Food and Dairy Microbiology. London: Academic Press.

Johnson, K. M. (1990). B. cereus food borne illness- an update. Journal of Food Protection, 47(2), 145-153.

Kabir, A., \& Niar, A. (2013). Quality Control of Milk in the Dairy Industry. World Journal of Dairy \& Food Sciences, 8(1), 18-26.

Kumaresan, G., \& Annalvilli, R. (2008). Incidence of Pseudomonas species in pasteurized milk. Tamilnadu Veterinary and Animal Sciences, 4, 56-59.

Mickova, V., Lukasova, J., \& Konencny, S. (1989). Pseudomonas aeruginosa in raw and pasteurized milk. Veterinary medicine, 34, 411-420.

Prevention of Food Adulteration (2007). Act, 1954 (Second Amendment) Rules. Universal Law Publishing Co. Pvt. Ltd., pp. 350.

Rajmohan, S., Dodd, C. E. R., \& Waites, W. M. (2002). Enzymes from the isolates of P. fluorescens involved in food spoilage. Journal of Applied Microbiology, 205-213. http://dx.doi.org/10.1046/j.1365-2672.2002.01674.x

Singh, P., Wani, A. A, Karim, A. A., \& Langowski, A. A., (2012). The use of carbon dioxide in the processing and packaging of milk and dairy products: A review. International Journal of Dairy Technology, 65, 161-177. http://dx.doi.org/10.1111/j.1471-0307.2011.00744.x

Sorhaug, T., \& Stepaniak, J. (1997). Psychrotrophs and their enzymes in milk and dairy products. Trends in Food Science \& Technology, 8, 35-41. http://dx.doi.org/10.1016/S0924-2244(97)01006-6

Todar, M. (2004). Pseudomonas aeruginosa in Web Review of Todar's Online Textbook of Bacteriology "The Good, the Bad, and the Deadly". Science Magazine, 304, 1-12.

United States Code of Federal Regulation. (2006). How heat treatment affect the final product. C.F.R. Title 21, part 131, Section 112.

\section{Copyrights}

Copyright for this article is retained by the author(s), with first publication rights granted to the journal.

This is an open-access article distributed under the terms and conditions of the Creative Commons Attribution license (http://creativecommons.org/licenses/by/3.0/). 